\title{
Competition as a Stimulating Factor in the Development of Science Intensive Sectors
}

\author{
Anukhina K.S. \\ Yaroslav-the-Wise Novgorod State University, \\ Veliky Novgorod, Russia \\ Burova I.A. \\ Yaroslav-the-Wise Novgorod State University, \\ Veliky Novgorod, Russia, \\ Irina.Burova@novsu.ru
}

\author{
Kirkorova L.A. \\ Yaroslav-the-Wise Novgorod State University, \\ Veliky Novgorod, Russia, \\ Lyudmila.Kirkorova@novsu.ru
}

\author{
Minina S.G. \\ Yaroslav-the-Wise Novgorod State University, \\ Veliky Novgorod, Russia
}

\author{
Trifonov V.A. \\ Yaroslav-the-Wise Novgorod State University, \\ Veliky Novgorod, Russia, \\ tva@novsu.ru
}

\begin{abstract}
The competitive struggle of economic entities is considered through the improvement of their products and services as a stimulating factor in the development of science intensive sectors. The purpose of the study is to determine the significance and role of innovations and high-tech industries as conditions for increasing the competitiveness of manufacturing companies based on the analysis of knowledge intensity of Russia. A brief description of the definition of «science intensive sectors», indicates the areas of production that most often use high-tech equipment and are science intensive is described. The situation related to competition and innovation in the global market is presented. It studies the level of knowledge-intensity of Russia by the financial component of scientific and technological capacity and by the staffing component based on government statistics. The competitive situation in the Russian market is considered based on empirical evidence presented in statistical compendiums. Both mathematical and empirical research methods are used drawing on official statistical information. The scientific novelty lies in an interdisciplinary consideration of the issue of competition, identifying resources and conditions for implementing innovations, determining the most popular areas of science intensive sectors, and highlighting innovative competition as the most important target tool for competition of manufacturers. As a result of the research, it was proved that competition is a stimulating factor in the development of science intensive sectors. Data on the use of funds and resources by Russian companies to research and development in order to improve their products and their competitiveness is provided.
\end{abstract}

Keywords - high-tech development of production, innovative activity, competition, science intensive sectors, scientific and technological capacity

\section{INTRODUCTION}

Innovation plays an important role for organizations today. In order for the company to remain successful and prosperous, it simply needs to keep up with the times and implement new high-quality ideas. Moreover, recently a new type of highquality economic development has appeared, which was called scientific and technical or innovative. Therefore, innovative entrepreneurship is seen as the most important tool in achieving the company's goals.

With the transition to a new level of social development post-industrial society - there has been a change in the factors and conditions of competitiveness, and the effectiveness of the subjects of production and economic activity. At the current level of development of economic systems, innovation now dominates as an instrument of competition between manufacturing companies. The very concept of competition, as rivalry for the distribution of economic benefits, now implies the emergence of new, more advanced technologies, new high-quality and functional products and, accordingly, the creation of new markets [1].

Consequently, innovation is at the heart of the development of cost and non-cost advantages for organizations. Thus, competition, which is the most important and necessary element of the market economy, at the same time appears in the form of a powerful stimulating mechanism for innovative activities of economic entities, which, in turn, creates the necessary conditions for the socio-economic development of the country and society as a whole [2]. 
A new type of rivalry between manufacturing companies appeared in the course of building up and developing innovative components and was called innovative competition [3]. The emergence of a new type of competition also implies the development of a new system of competitive relations with new approaches to their regulation. Currently, the main factor for the success of production activities is the efficiency of innovation, and its spread is not limited to product markets, it is also present in the labor and capital markets.

The aim of the study is to study competition as a stimulating factor for pushing towards innovative, knowledgeintensive production, which creates the necessary conditions for the development of the country's economy and society as a whole.

The objectives of the research are to analyze the competitive situation in the Russian market, study the most significant areas of the science intensity of production in Russia, and present the results of the level of science intensity in Russia.

\section{RESEARCH METHODS}

The analysis was carried out with the help of mathematical and empirical research methods, etc. The cost approach and the approach to the personnel component were used to determine the level of science intensity.

The Director General of the World Intellectual Property Organization said that the foundation in the global economy today is mainly knowledge, which is why innovation is a stimulating factor for economic growth. Thus, more and more mandatory additional investments are required, because they will help stimulate the generation and subsequent implementation of creative ideas and, as a result, increase production volumes. That is, innovation can become a lever that can transform economic recovery into long-term growth $[4,5]$.

Russia ranks 47th in the global innovation index. This is an indicator that contains 82 different variables that most fully characterize the innovative development of countries around the world that differ in terms of economic development. The global innovation index can be calculated as a weighted sum of estimates for the groups of indicators indicated below [6, 7 , 8]:

1). The country's innovative resources and the existence of such conditions in which these resources can be used. This group includes the following indicators:

- infrastructure,

- human capital,

- research,

- institutes,

- development of the domestic market,

- business development;

2). The results of innovation activity achieved in practice, which can be measured or converted into numbers:

- technologies, knowledge economy, their development;
- the results of creative activity.

These groups of indicators are used because experts have identified the dependence of the success of the economy with the availability of innovation potential and with the conditions for its implementation.

Thus, the result is a ranking of countries, which reflects the ratio of costs and benefits. This, in turn, helps to assess from an objective point of view, what efforts and with what success this or that country realizes its innovative potential. In Russia, a huge innovation potential lies in high-tech industries that need to be developed and stimulated.

Science-intensive production is a production in which it is necessary to make a significant amount of calculations, scientific research and experiments before releasing finished products [9]. Also, in high-tech industries, more than $60 \%$ of the costs associated with the development and release of products are allocated to research and development work (R\&D) [10]

Distinctive features of science-intensive industries are [11]:

- fundamental directions and research include advanced science and scientific schools;

- efficiency and accessibility of the education system, which is a significant factor in the training of highly qualified personnel;

- specific needs for scientific and technical innovations that have appeared in society at the present time;

- protection of intellectual property rights, including the diffusion of innovations, as an important factor in innovation, has a high level of development, effectively working at every stage;

- a number of industries are of national importance for solving issues of technological independence and defense capability of the country;

- innovative projects and production require state support, which plays a key role at the stage of their inception;

- the structure of mass production contains high unit costs for R\&D;

- only advanced technologies are used in mass production;

- experimental and pilot production have a high share in the structure of the production apparatus of the economy;

- innovative and investment activities are actively and effectively functioning, etc.

Fig. 1 shows the areas of knowledge and production that are considered the most knowledge-intensive [12].

Competition in world markets is significantly enhanced by new trends and tendencies in the development of the world economy; they also transform the structure of factors influencing competition, to a large extent in favor of non-price and technological ones. 
The factors of production are inevitably transformed and, as a result of the transition to modern productive forces, they form a new trend: high-tech production is focused on the individualization of the needs and demands of consumers, while maintaining their production properties. This trend has served the progressive development of scientific and technological progress and the exhaustion of intensive development opportunities.

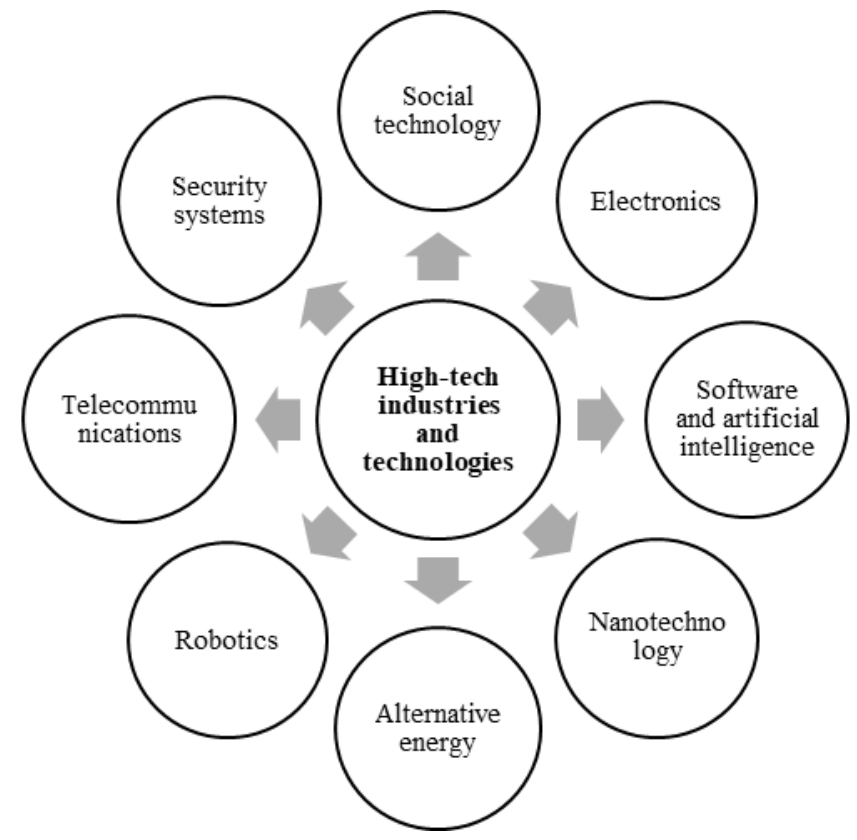

Fig. 1. The most popular areas of knowledge-intensive industries

As a result, production in all developed countries was guided mainly by individual needs, and mass centralized production has lost its competitiveness. All manufacturers who have caught the new trend in development began to occupy the top positions in the competition, and as a result, countries are becoming technological leaders.

For example, the Russian automotive industry, due to the technical backwardness of Russian car manufacturers, is an industry with low competitiveness: Russia has a share not exceeding $2.8 \%$ in the world market, including $0.26 \%$ in terms of exports [13].

\section{FINDINGS}

Rosstat data make it possible to calculate the indicator of the level of science intensity on a cost basis (in terms of the financial component of scientific and technical potential) and in terms of the personnel component - these are some of the existing methods, which are most used for quantitative assessment of the level of science intensity in industries [14, $15,16]$.

The results of calculating the level of knowledge intensity, calculated using the methods described above, are presented in Tables I and II.

$\mathrm{K} 1$ is an indicator of the level of science intensity, it is calculated as the ratio of R\&D costs to the level of Russia's GDP. K2 is an indicator of the level of science intensity, it is calculated as the ratio of $R \& D$ costs to capital investments [17].
TABLE I. THE LEVEL OF SCIENCE INTENSITY IN RUSSIA (COST APPROACH)

\begin{tabular}{|c|c|c|c|c|c|}
\hline \multirow{3}{*}{ Year } & \multirow[t]{2}{*}{ GDP } & \multirow{2}{*}{$\begin{array}{c}\text { Capital } \\
\text { investments }\end{array}$} & \multirow[t]{3}{*}{$R \& D$ costs } & \multirow{2}{*}{\multicolumn{2}{|c|}{$\begin{array}{c}\begin{array}{c}\text { Level of science } \\
\text { intensity }\end{array} \\
\%\end{array}$}} \\
\hline & & & & & \\
\hline & \multicolumn{2}{|r|}{ billion rubles } & & $\kappa 1$ & $\kappa 2$ \\
\hline 2011 & 60282.5 & 11035.7 & 610.4 & 1.01 & 5.53 \\
\hline 2012 & 68163.9 & 12586.1 & 699.9 & 1.03 & 5.56 \\
\hline 2013 & 73133.9 & 13450.2 & 749.8 & 1.03 & 5.57 \\
\hline 2014 & 79199.7 & 13902.6 & 847.5 & 1.07 & 6.10 \\
\hline 2015 & 83232.6 & 13897.2 & 914.7 & 1.10 & 6.58 \\
\hline 2016 & 86010.2 & 14748.8 & 943.8 & 1.10 & 6.40 \\
\hline 2017 & 92089.3 & 16027.3 & 1019.2 & 1.11 & 6.36 \\
\hline 2018 & 103626.6 & 17595.0 & 1028.2 & 0.99 & 5.84 \\
\hline 2019 & 110046.1 & 19319.3 & 1134.8 & 1.03 & 5.87 \\
\hline
\end{tabular}

Table I shows that over 9 years the level of science intensity in Russia has not changed significantly, although during this time there were peaks of growth in the indicator in 2015-2017.

TABLE II. THE LEVEL OF SCIENCE INTENSITY IN RUSSIA (IN TERMS OF PERSONNEL)

\begin{tabular}{|c|c|c|c|}
\hline \multirow{2}{*}{ Year } & $\begin{array}{c}\text { Total number of } \\
\text { personnel }\end{array}$ & $\begin{array}{c}\text { Number of } \\
\text { scientific personnel }\end{array}$ & $\begin{array}{c}\text { Level of science } \\
\text { intensity }\end{array}$ \\
\cline { 2 - 4 } & \multicolumn{2}{|c|}{ Thousand people } & \% \\
\hline 2011 & 70856.6 & 735.273 & 1.04 \\
\hline 2012 & 71545.4 & 726.318 & 1.02 \\
\hline 2013 & 71391.5 & 727.029 & 1.02 \\
\hline 2014 & 71539.0 & 732.274 & 1.02 \\
\hline 2015 & 72323.6 & 738.857 & 1.02 \\
\hline 2016 & 72392.6 & 722.291 & 1.00 \\
\hline 2017 & 72142.0 & 707,887 & 0.98 \\
\hline 2018 & 72354.4 & 682.580 & 0.94 \\
\hline 2019 & 71764.5 & 682.464 & 0.95 \\
\hline
\end{tabular}

The data presented in Table II show that the level of science intensity, calculated on the basis of the personnel component, decreased by $0.09 \%$ over the period under review, which indicates a stable reduction in scientific personnel in Russia. The assessment of the state of the competitive environment in Russia in 2019, carried out by the Analytical Center for the Government of the Russian Federation, shows the highest level of competition in the Russian market [18]. Moreover, manufacturers increased the competitiveness of their industries by investing in $\mathrm{R} \& \mathrm{D}, 80 \%$ of food manufacturers invested heavily in the purchase of high-tech equipment, representatives of the metallurgical industry in the amount of $72 \%$ of the total market also made these investments.

Enterprises of the agricultural sector (71\%) actively invested in innovative equipment in order to increase production volumes, as well as reduce the labor intensity of products. For example, OAO (OJSC) "Velikoluksky Meat Processing Plant" opened two new workshops, in which it launched four new technological lines for the production of products. 
Manufacturers of non-metallic products and building materials also caught the trend of increasing competitiveness, by increasing the manufacturability of production - $68 \%$ of representatives of this field purchased new high-tech equipment. Manufacturers of electronic and optical equipment, as well as machinery and equipment made a contribution to their own R\&D, their share was $65-68 \%$, and representatives of the food $(60 \%)$ and woodworking $(50 \%)$ industries entered new food markets due to innovative activities. New technologies, patents, licenses, know-how for 2019 were in wide demand in the field of education (36\%) [18]. In 2020 , manufacturers of non-metallic products - $86 \%$ and representatives of the textile industry - $80 \%$ took the first place in the purchase of high-tech equipment [19]. Manufacturers of woodworking and transport engineering (their share was 50\%) carried out their own R\&D.

\section{CONCLUSION}

Thus, at present, economic entities need constant modernization of their products and the release of a fundamentally new product, which is associated with the emergence of specific requirements on the part of consumers, great importance is given to innovation and high-tech production. This, in turn, gives rise to competition in innovation and the emergence of new knowledge-intensive industries. In order to achieve a leading position, it is not necessary to be a corporation with many years of experience, first of all, you need ideas, knowledge of the market and a competent approach to business organization. And in order to improve the position of our country in the field of innovative business, it is necessary to create conditions for more startups to implement their ideas, and companies that are already operating in the market, improve their production methods.

During the study, it was revealed that for the period from 2011 to 2019, the science intensity (in terms of value) in Russia returned to the level of 2011. This was due to the reduction in the costs of research and development work in the gross domestic product of Russia. The level of science intensity in terms of the personnel component also decreased over the period under review. This indicates the loss of scientific personnel from various industries. It was also revealed that in 2019 the level of competition reached its maximum value in the last 5 years, as noted by the respondents from the business sector. To increase their competitiveness, most enterprises from various industries invested resources, namely, in high-tech equipment or developed and carried out their own research and development work.

\section{References}

[1] T.V. Matveeva, V.V. Krivorotov., N.V. Mashkova, and P.P. Korsunov, Increasing the competitiveness of industrial enterprises based on the development of innovative activity: textbook manual [Povysheniye Konkurentosposobnosti Promyshlennykh Predpriyatiy na Osnove Razvitiya Innovatsionnoy Deyatel'nosti: uchebnoye posobiye], Yekaterinburg: Publishing House of Ural University, 2018. (In Russ.).

[2] R.A. Chursin, A.V. Yudin, P.Yu. Grosheva., P.G. Filippov, and E.V. Butrova, "Tool for Assessing the Risks of R\&D Projects Implementation in High-tech Enterprises", in Proceedings of IOP Conference Series: Materials Science and Engineering, 2019, pp. 1-7. (In Russ.). Retrieved from https://iopscience.iop.org/article/10.1088/1757$899 \mathrm{X} / 476 / 1 / 012005 / \mathrm{pdf}$
[3] A. Karman, and A. Savaneviciene A., Enhancing dynamic capabilities to improve sustainable competitiveness: insights from research on organisations of the Baltic region, 2020. Retrieved from https://www.emerald.com/insight/content/doi/10.1108/BJM-08-20200287/full/pdf?title=enhancing-dynamic-capabilities-to-improvesustainable-competitiveness-insights-from-research-on-organisations-ofthe-baltic-region

[4] A. Sukumar, V. Jafari-Sadeghi, A. Garcia-Perez, and D.K. Dutta, The Potential Link between Corporate Innovations and Corporate Competitiveness: Evidence from IT Firms in the UK, 2020. Retrieved from https://www.emerald.com/insight/content/doi/10.1108/JKM-10 2019-0590/full/pdf?title=the-potential-link-between-corporateinnovations-and-corporate-competitiveness-evidence-from-it-firms-inthe-uk

[5] N.A. Tretyak, S.V. Gubarkov, I.V. Zhupley, and I.I. Dyakov, "Innovative Development of Higher Education Institutions in the Context of Competition and Network Cooperation", Revista Espacios, 2019, vol. 40(31), p. 15. Retrieved from http://www.revistaespacios.com/a19v40n31/a19v40n31p15.pdf

[6] Humanities. Analytical portal. Global Innovation Index, 2020. . (In Russ.). Retrieved from http://gtmarket.ru/ratings/global-innovationindex/info

[7] The Global Innovation Index, 2020. Retrieved from http://www.wipo.int/edocs/pubdocs/en/wipo_pub_gii_2017.pdf

[8] WIPO IP Statistics Data Center, 2020. Retrieved from https://www3.wipo.int/ipstats/index.htm?tab=patent

[9] N.Z. Nabil., B. Cerit, and A. Hodgson, Technology Roadmapping for the Next Generation Manufacturing Enterprise Region, 2016. Retrieved from

https://www.emerald.com/insight/content/doi/10.1108/17410380610662 843/full/pdf?title=technology-roadmapping-for-the-next-generationmanufacturing-enterprise

[10] A.S. Puryaev, Organization of High-tech Production. Study guide for students of the direction of training 38.04.02 [Organizatsiya Naukoyemkogo Proizvodstva. Uchebno-metodicheskoye posobiye dlya studentov napravleniya podgotovki 38.04.02], Naberezhnye Chelny: NCHI KFU, 2019. (In Russ.).

[11] O. Kolomyts, V. Prokhorova, and I. Ivanova, Advantages and Prospects of Creating Regional High-tech Agrarian, 2019. (In Russ.). Retrieved from

https://zenodo.org/record/2615327/files/356.Manuscript\%20Prokhorova 2converted.pdf?download $=1$

[12] N.A. Ovcharenko, T.N. Sidorenko, and E.P. Novikova, Fundamentals of managing the development of competition in the constituent entities of the Russian Federation: textbook manual [Osnovy Upravleniya Razvitiyem Konkurentsii v Sub"yektakh Rossiyskoy Federatsii. Uchebnoye posobiye], Krasnodar: Krasnodar Center for Scientific and Technical Information, 2016. (In Russ.).

[13] Russia in Numbers. Brief statistical compilation [Rossiya v Tsifrakh. Kratkiy Statisticheskiy Sbornik], 2019. (In Russ.). Retrieved from https://rosstat.gov.ru/free_doc/doc_2019/rusfig/rus19.pdf

[14] Investments in Russia 2019: Statistical Compilation, Moscow: Rosstat 2019 (In Russ.). Retrieved from https://rosstat.gov.ru/storage/mediabank/Invest_2019.pdf

[15] Federal State Statistics Service. Science and Innovation. (In Russ.) Retrieved from https://rosstat.gov.ru/folder/14477

[16] Federal State Statistics Service. The number of employed persons aged 15 and over in the constituent entities of the Russian Federation. (In Russ.). $\quad$ Retrieved from https://rosstat.gov.ru/storage/mediabank/b4WGs2Tk/trud2_15-72.xls

[17] Federal State Statistics Service. Methodology for calculating the indicator "Level of innovative activity of organizations", 2019. (In Russ.) Retrieved https://rosstat.gov.ru/storage/mediabank/pr818.pdf

[18] Analytical Center for the Government of the Russian Federation. Assessment of the state of the competitive environment in Russia, 2019. (In Russ.). Retrieved from https://ac.gov.ru/files/publication/a/21420.pdf Analytical Center for the Government of the Russian Federation. Assessment of the state of the competitive environment in Russia, 2020. (In Russ.). Retrieved from https://ac.gov.ru/uploads/2Publications/Konkurenciya_doklad_2020.pdf 